\title{
The role of cover crops for cropland soil carbon, nitrogen leaching, and agricultural yields - A global simulation study with LPJmL (V. 5.0-tillage-cc)
}

Vera Porwollik ${ }^{1,2}$, Susanne Rolinski ${ }^{1}$, Jens Heinke ${ }^{1}$, Werner von Bloh ${ }^{1}$, Sibyll Schaphoff ${ }^{1}$, Christoph Müller ${ }^{1}$

${ }^{1}$ Potsdam Institute for Climate Impact Research, Member of the Leibniz Association, P.O. Box 6012 03, 14412 Potsdam, Germany

${ }^{2}$ Department of Agricultural Economics, Humboldt-University of Berlin, Unter den Linden 6, 10099 Berlin, Germany

Correspondence to: Vera Porwollik (verapor@pik-potsdam.de)

Abstract. Land management practices can reduce the environmental impact of agricultural land use and production, improve productivity, and transform cropland into carbon sinks. We applied the global vegetation model LPJmL5.0-tillage-cc with a modified representation of cover crop practices. We assessed simulated responses to cover crop practices on agroecosystem components in comparison to bare soil fallow between two consecutive primary crops' growing seasons on global cropland for a simulation period of 50 years. With cover crops and tillage, we obtained annual global median soil carbon sequestration rates of 0.52 and $0.48 \mathrm{t} \mathrm{C} \mathrm{ha}^{-1} \mathrm{yr}^{-1}$ for the first and last decades of the entire simulation period, respectively. We found that cover crops with tillage reduced annual nitrogen leaching rates from cropland soils by a median of $39 \%$ and $54 \%$ but also the productivity of the following main crop by average of $1.6 \%$ and $2 \%$ for the two analyzed decades. Largest reduction of productivity were found for rice, modestly lowered for maize and wheat, whereas soybean yield revealed an almost homogenous positive response to cover crop practices during fallow periods.

Further, the results suggest that no-tillage is a suitable complementary practice to cover crops, enhancing their environmental benefits and reducing potential trade-offs with the main crop productivity due to their impacts on soil nitrogen and water dynamics. For cover crops applied in conjunction with no-tillage across the mapped Conservation Agriculture cropland area for the period 1974-2010, we estimated a cumulative soil carbon netaccumulation of $1.4 \mathrm{PgC}$, an annual median reduction of soil nitrogen leaching by $57 \%$, as well as mostly enhanced yields of the following main crop.

The spatial heterogeneity of simulated impacts of cover crops on the variables assessed here was related to the time period since the introduction of the management practice as well as to environmental and agronomic conditions of the cropland. This study supports findings of other studies, highlighting the substantial potential contribution of cover crop practices to the sustainable development of arable production.

\section{Introduction}

The agricultural sector is challenged to provide more food, feed, and fuel to meet an increasing demand due to global human population dynamics as well as changes in diet composition (Alexander et al., 2017; Bodirsky et al., 2015; Godfray et al., 2010). Simultaneously, it is expected to consume fewer resources either by direct savings or by increasing general efficiency of applied inputs (Lal, 2004a; Springmann et al., 2018). Agricultural production accounts for $\sim 10 \%$ (mean of the years 2007 to 2016) of the annual global anthropogenic greenhouse 
gas emissions, including carbon (C) dioxide, methane from ruminant animals, as well as nitrous oxide emissions from crop production (i.e. fertilizer) and livestock rearing activities (Rosenzweig et al., 2020). A loss of 30 to 40

\% soil organic C was estimated due to the historic cultivation of croplands (Poeplau and Don, 2015). Additional

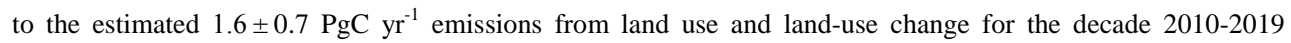

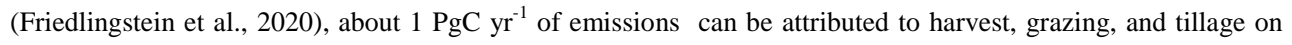
global cropland in the period since year 1850 (Pugh et al., 2015). At the same time, agricultural land management practices can be employed to reduce or reverse detrimental environmental impacts of agricultural production as well as facilitate the regeneration of degraded ecosystem functions (Rosegrant et al., 2014). Conservation Agriculture (CA) practices have been proposed to improve cropland soil fertility and to sustain productivity (Scopel et al., 2013; Thierfelder et al., 2018; Tittonell et al., 2012). CA comprises minimum mechanical soil disturbance, the maintenance of a permanent vegetative soil surface cover, and a diversified crop rotation (Kassam et al., 2019). The latter two aspects can be accomplished by the integration of a secondary crop, which depending on the position and purpose in the rotation, can be referred to as green manure, intercrop, or as intermediate, companion, catch, and cover crop (term further used in this study). For farming systems cultivating annual crop types, cover crops can be grown between two consecutive main cropping seasons, whereas for perennial woody crops, cover crops are rather found as groundcovers between trees (GonzalezSanchez et al., 2019). Cover crops exhibit several environmental benefits such as decreasing nitrogen (N) leaching from agricultural systems (Abdalla et al., 2019; Thapa et al., 2018; Tonitto et al., 2006; Valkama et al., 2015). The $\mathrm{N}$ recovery rate of excess fertilizer left in the soil after harvest of a main crop is found to be higher for non-leguminous species (such as grasses, e.g. ryegrass (Florentín et al., 2011) and brassicas, e.g. radish) than for leguminous (e.g. peas and beans) cover crop species (Dabney et al., 2011). Leguminous types are able to improve the $\mathrm{N}$ balance of the soil (Kaye and Quemada, 2017) through additional N fixation and by this may reduce fertilizer input requirements in the long term (Nouri et al., 2020; Thierfelder et al., 2018). Last but not least, cover crops constitute a suitable measure for weed control and against soil compaction (SARE, 2019), as well as erosion prevention through extending the vegetative coverage of the soil surface (Kaye and Quemada, 2017). Cover crops are terminated either naturally (e.g. by frost), chemically (e.g. by herbicide application), or mechanically (e.g. by mowing, roller, tillage) (Kaye and Quemada, 2017). The corresponding biomass of the cover crops can be harvested for off-field usages, grazed by livestock, or if left on the field, be used to build up the soil’s humus layer (Florentín et al., 2011). Cover crops are an important practice to manage soil fertility and weed in organic farming systems (Keestra et al., 2018).

According to the Farm Structure Surveys and the Survey on Agricultural Production Methods (SAPM), which are carried out on a 10 year interval as a census in the EU-28 countries, the soil surface of arable land during winter of the year 2010 was covered: $44 \%$ with normal winter crops, $5 \%$ with cover or intermediate crops, $9 \%$ with plant residues, and $25 \%$ left as bare soil. The remaining $16 \%$ missing reporting share comprise areas under glass and areas not cultivated during the reference year (e.g. temporary grassland, hops) (EUROSTAT, 2018). Poeplau and Don (2015) report that current shares of cropland with cover crops range between 1-10 \% for countries in Europe and the US. Further, these authors estimate 400 million hectares cropland area suitable for cover crop practices as half of the global winter or off-season fallow cropland, by excluding $50 \%$ of the total area covered with winter cereals and further $25 \%$ of the off-season fallow area due to climatic or agronomical constraints. This area estimate is also used in Kaye and Quemada (2017), who find the mitigation potential of 
cover crop practices mainly due to the combined effects of soil C sequestration, reduced fertilizer application rates, and changes in surface albedo, corresponding to an off-set of about $10 \%$ of the estimated annual emissions from agriculture. Cover crop practices encompass potential to contribute to climate change impact mitigation through soil C sequestration (Abdalla et al., 2019; Corsi et al., 2012; Poeplau and Don, 2015). Largest potentials for the realization of $\mathrm{C}$ sequestration on global cropland soils were identified for areas with high natural potential soil C stocks and with strongest C depletion due to duration and intensity of historical agricultural land use and management (Sommer and Bossio, 2014), resulting in a larger saturation deficit (West and Six, 2007). Cover crop practices serve adaptation through improving the efficiency of applied inputs (i.e. fertilizer) and increasing the resilience of cropland production (Kaye and Quemada, 2017; Rosenzweig et al., 2020).

The objectives of this study were to: i) Assess the temporal and spatial pattern of cover crop impacts simulated with LPJml5.0-tillage-cc on global cropland soil C stocks, $\mathrm{N}$ leaching rates, and agricultural productivity, ii) Quantify responses to the practices applied with tillage and the influence of management duration, and iii) Estimate the effects of cover crops combined with no-tillage for mapped CA cropland as well as their potential contribution to mitigation and adaptation efforts.

\section{Methods and data}

\subsection{Simulating cover crop practices with LPJmL5.0-tillage-cc}

For the assessment of cover crop cultivation impacts, we applied the dynamic global vegetation model

LPJmL5.0-tillage-cc, representing biophysical and biogeochemical processes of the biosphere for the quantification of human-nature interactions as well as of their impacts on natural and managed ecosystems. A detailed description of water, soil, and plant dynamics of a preceding model version 4, including a comprehensive evaluation of model skills, is provided in Schaphoff et al. (2018a); (2018b). The here used model version additionally includes processes associated to global $\mathrm{N}$ dynamics in soils and plants (von Bloh et al., 2018), as well as an explicit representation of tillage types and crop residue management (Lutz et al., 2019). Herzfeld et al. (2021) examine global soil carbon dynamics affected by historical land-use change, tillage, and crop residue management, based on simulations with LPJml5.0-tillage2 comprising a similar model code and management representation as applied here.

We used LPJmL5.0-tillage-cc with a modified code for the representation of cover crop management. It is built on an earlier version of the model accounting for 'intercrops', as the options to simulate either vegetated (natural grass) or bare soil fallow dynamics on cropland area in the period between two consecutive primary crops' growing seasons (Bondeau et al., 2007). The functionalities make use of three 'grass' plant functional types (PFTs), already implemented in LPJmL for the natural vegetation, growing on fallow cropland area according to their bio-climatic limits as tropical C4, temperate C3, and polar C3 grass (Forkel et al., 2014). In the model, biophysical and biogeochemical dynamics on off-season cropland within a grid cell, are accounted for in routines of the 'setaside stand'. The 'intercrop' carbon-only version of LPJmL and 15 other agroecosystem models were included in the study of Kollas et al. (2015). They find only minor ability of the model ensemble, to reproduce the slight positive main crop yield effect, which was observed in the experimental sites for rotations with intermediate crops. 
We modified the functionalities for the establishment of cover crop (grass), so that it occurs on each crop specific off-season cropland fraction after harvest of the main crop (CFT) within a grid cell. The initial biomass of the cover crop grass sapling (0.05-0.07 $\mathrm{g} \mathrm{C} \mathrm{m}^{-2}$ ) was changed to be taken from the respective $\mathrm{C}$ and $\mathrm{N}$ pools of the soil litter layers. We did so, to avoid imposing artificial fertilization effects (Olin et al., 2015), from simply adding contained amounts of the sapling's $\mathrm{C}$ and $\mathrm{N}$ to the simulated system with the default CFTs establishment model routines, which assume crop seeds as external inputs.

In this model version, $\mathrm{C}$ and $\mathrm{N}$ are allocated to the different organs (root and leaf pools) of the cover crop grass plants on a daily basis, using routines of 'managed grassland' dynamics described in Rolinski et al. (2018) and von Bloh et al. (2018). Any management of the cover crops growing as grasses on fallow cropland area was excluded. Cover crops are terminated at the beginning of the following main crop growing season. The corresponding aboveground grass plant biomass is either left at the soil surface, or transferred to the incorporated soil litter pools, depending on the tillage setting. The root biomass of the terminated cover crops is added to the respective belowground litter pools. Soil and vegetation C, N, and water fluxes in the main crop growing period as well as during vegetated or bare fallow off-season were summarized in model outputs for the entire cropland. More details of the model functionalities, and input data used, are provided in the Supplement (Sect. S1).

\subsection{Simulation setup land management scenarios}

All simulations were run at a spatial resolution of 0.5 x 0.5 arc degrees. As a first step, we conducted a 7000 years spin-up simulation with LPJmL5.0-tillage-cc, in order to get natural vegetation pattern and soil pools into a dynamic equilibrium state, recycling the first 30 years of climate input data following the procedures described in von Bloh et al. (2018).

Subsequently, we ran a second spin-up simulation, with fixed cropland distribution pattern and most of the land management as provided by the model input data for the year 2010 (Sect. S1.2). We assumed bare soil fallow on cropland during the main crops off-season periods as well as tillage to be the default historical management practices. By keeping land use and management constant during these simulation steps, we assume that cropland had been already cultivated for a longer period at the beginning of the actual simulation period so that results can be more easily compared to literature values e.g., obtained from experiments conducted on already established cropland area plots. Starting with cropland soil pools from this spin-up procedure, we simulated the control scenario as reference (REF) maintaining all settings as during the land use spin-up. Three alternative management scenarios were generated with cover crops (CC), no-tillage (NT) applied as single, and as combined practices (CCNT) on global cropland for a 50 year simulation period (see Supplement Table S1.3 for more details on simulation setup). On the one hand, this time frame has been stated as minimum duration required to re-establish a new steady state in soil C pools after the introduction of a new soil management practice involving altered biomass input levels (Kaye and Quemada, 2017; Poeplau and Don, 2015). On the other hand, the 50 years were chosen for analysis because of spanning the maximum duration found for values in literature and here used for evaluating simulated responses. 


\subsection{Post-processing model outputs}

Model output data was post-processed and analyzed with R version 3.3.2 (R Development Core Team, 2016), applying functions developed by Kowalewski (2016) as well as by using the packages 'raster' (Hijmans and van Etten, 2012), 'reldist' (Handcock, 2016), and 'ncdf4' (Pierce, 2015).

Soil C stock change was quantified up to a $30 \mathrm{~cm}$ soil depth by adding C pool model outputs for the litter, the first soil layer (0-20 cm soil depth), and one third of the second soil layer (20-50 cm soil depth). Responses of cropland soil C stock to altered management scenario in comparison to the control (REF) were generated, assuming a 'paired plot' (West et al., 2004) or 'synchronic' approach (Corbeels et al., 2018). The calculations follow the equation 3.3.4B of the guidance from the Intergovernmental Panel on Climate Change (IPCC, 2006) for annual changes in mineral soil C stock on remaining cropland as Eq. (1):

$\Delta p_{s, i, t}=\left(p_{s, i, t}-p_{R E F, i, t}\right) / T_{i, t}$,

where $\Delta p_{s, i, t}$ is the annual soil C sequestration rate in $\mathrm{t} \mathrm{Cha}^{-1} \mathrm{yr}^{-1}$ per alternative scenarios $s$, in grid cell $i$, and time step $t$, as the absolute difference between the annual absolute soil C stock $p_{s, i, t}$ in $\mathrm{C} \mathrm{ha}^{-1} \mathrm{yr}^{-1}$ in each of the alternative scenarios and the baseline $p_{R E F, i, t}$, divided by management duration $T$, as the number of years ( 1 to 50) since introduction of the alternative practices.

Simulated annual productivity output data for the four crop types: wheat, maize, rice, and soybean were averaged, as area-weighted mean of irrigated and rainfed yield in $\mathrm{kg} \mathrm{DM} \mathrm{ha}^{-1} \mathrm{yr}^{-1}$, per crop-specific cropland area in grid cell $i$, and time step $t$.

Responses to altered management of crop-specific average yield in $\mathrm{kg} \mathrm{DM} \mathrm{ha}^{-1} \mathrm{yr}^{-1}$ and $\mathrm{N}$ leaching rates $\mathrm{kg} \mathrm{N}$ ha ${ }^{1} \mathrm{yr}^{-1}$, respectively, were computed as Eq. (2):

$\Delta v_{s, i, t}=\left(\left(\frac{v_{s, i, t}}{v_{R E F, i, t}}\right)-1\right) * 100$,

where $\Delta v_{s, i, t}$ is the relative difference in percent (\%) between the assessed variable $\left(v_{s, i, t}\right)$ per alternative management scenario $s$ compared to the baseline value $\left(v_{R E F, i, t}\right)$, per hectare of cropland area in grid cell $i$, and time step $t$.

We report global aggregates of values and differences as area-weighted median (Q2 as $\mathrm{q}=0.5$ as $\Delta \tilde{v}_{s, i, t}$ ), the first (Q1 as q $=0.25$ ) and third quartile (Q3 as $\mathrm{q}=0.75$ ) per scenario $s$, per time step $t$. Time step $t$ is annual (yr ${ }^{1}$ ) either reported for the first (years 1 to 10 ) and last (years 41 to 50 ) decade of the 50 simulation years to contrast short from long term effects, or for an else indicated time period. For area-weighting of the global aggregates, we applied the physical cropland distribution pattern of land use model input data of the year 2010 (see Sect. 2.2, S1.2). Although many studies present averages across experiment sites and years (Nyawira et al., 2016), we computed median (and quartiles) changes to exclude outliers stronger influence on global spatial aggregated mean values.

To assess historical global impact of Conservation Agriculture on agroecosystem components, we employed a time series dataset of global gridded CA physical cropland area. This CA data was generated, using annual national reported CA cropland area data in hectares (FAO, 2016) and employing methods described in Porwollik et al. (2019) and further in the Supplement (Sect. S1.4). The simulation cover crops combined with no-tillage (CCNT) was assumed a proxy for the suite of CA practices. Computed changes per variable, grid cell $i$, time step $t$ for the CCNT scenario compared to the control (REF), were remapped to match the historically evolving 
spatial and temporal pattern of the CA cropland area time series data. We quantified impacts of CCNT on variables as global aggregated total and as area-weighted median change per hectare of CA cropland area for the years 1974 to 2010. During this assessed historical period the CA area grew from a share of 0.2 to $10 \%$ of the global cropland area (FAO, 2016).

\section{Results}

\subsection{Overview of aggregated responses to cover crops}

Simulated cover crop impacts exhibit positive soil carbon sequestration rates and reduced $\mathrm{N}$ leaching rates, but at the cost of lowered average yield in both analyzed decades (Table 1). The here estimated changes of agroecosystem components due to cover crops (CC) compared to bare fallow (REF) on cropland between two consecutives main crop growing seasons, are consistent with the magnitude and direction of effects reported in other studies (Table 1, see Supplement Table S2.1 for an extended comparison to literature values).

Table 1. Responses to cover crops (CC) in comparison to the control scenario with bare fallow (REF) on cropland during main crop off-season periods as annual aggregated area-weighted median and in the parenthesis the quartiles (Q1, Q3) for the first and last decades of the 50 year simulation period, respectively, (see Sect. 2.3 for equations used). In the latter two columns values from other studies as well as their considered duration of cover crop management are reported.

\begin{tabular}{lccccc}
\hline $\begin{array}{l}\text { Response } \\
\text { Variable }\end{array}$ & $\begin{array}{c}\text { Unit } \\
\text { per } \\
\text { year }\end{array}$ & $\begin{array}{c}\text { Simulated } \Delta \mathbf{C C} \\
\text { first decade } \\
\text { median (quartiles) }\end{array}$ & $\begin{array}{c}\text { Simulated } \Delta \mathbf{C C} \\
\text { last decade median } \\
\text { (quartiles) }\end{array}$ & $\begin{array}{c}\text { Literature } \Delta \mathbf{C C} \\
\text { range of values } \\
\text { (min.-max.) }\end{array}$ & $\begin{array}{c}\text { Management } \\
\text { duration } \\
\text { (years) }\end{array}$ \\
\hline $\begin{array}{l}\text { Soil C } \\
\text { sequestration }\end{array}$ & $\mathrm{t} \mathrm{C} \mathrm{ha}^{-1}$ & $0.52(0.03,1.04)$ & $0.48(0.24,0.78)$ & $0.01-0.56^{\mathrm{a}}$ & $1-54$ \\
rate & & & & & \\
N leaching rate & $\%$ & $-39.3(-64.2,-3.6)$ & $-54.3(-74.4,-35.8)$ & $-70-(-50)^{\mathrm{b}}$ & $1-17$ \\
Wheat yield & $\%$ & $-0.7(-3.5,0)$ & $-1.4(-5.3,-0.1)$ & & \\
Rice yield & $\%$ & $-5.6(-9.9,-0.3)$ & $-5.6(-9.8,-2.5)$ & & 5 \\
Maize yield & $\%$ & $0(-6.0,0.1)$ & $-1.2(-11.5,0.6)$ & $0-9.6^{\mathrm{c}}$ & 5 \\
Soybean yield & $\%$ & $0.1(0,1.0)$ & $0.4(0,2.7)$ & $2.8-11.6^{\mathrm{d}}$ & $1-28$ \\
Average yield & $\%$ & -1.6 & -2.0 & $-4-0^{\mathrm{e}}$ & 5
\end{tabular}

a Jian et al. (2020); Lal (2004b); Paulsen (2020); Poeplau and Don (2015); Sommer and Bossio (2014);

Stockmann et al. (2013)

${ }^{\mathrm{b}}$ Thapa et al. (2018); Tonitto et al. (2006); Valkama et al. (2015)

${ }^{c}$ Marcillo and Miguez (2017); SARE (2019)

${ }^{\mathrm{d}}$ SARE (2019)

e Abdalla et al. (2019); Thapa et al. (2018); Tonitto et al. (2006); Valkama et al. (2015) 


\subsection{Soil carbon responses to altered management and duration}

We found increased cropland soil carbon stocks in the three alternative management scenarios compared to the control (REF), indicated by positive annual area-weighted spatial aggregated median soil carbon sequestration rates (Fig. 1, for respective spatial patterns see Fig. S2.3.1). During the first decade the median soil C sequestration rates in the three alternative management scenario simulations CC, CCNT and NT were higher (0.52, 0.72, and $\left.0.08 \mathrm{t} \mathrm{C} \mathrm{ha}^{-1} \mathrm{yr}^{-1}\right)$ than during the last decade $\left(0.48,0.54\right.$, and $\left.0.01 \mathrm{t} \mathrm{C} \mathrm{ha}^{-1} \mathrm{yr}^{-1}\right)$. The maximum annual median soil C sequestration rates within both cover crop scenarios CC and CCNT $\left(0.79,1.03 \mathrm{t} \mathrm{C} \mathrm{ha}^{-1} \mathrm{yr}^{-}\right.$ ${ }^{1}$ ) were reached in the sixth year of the analyzed 50 year simulation period, whereas in NT $\left(0.11 \mathrm{t} \mathrm{C} \mathrm{ha}^{-1} \mathrm{yr}^{-1}\right)$ already in the third year since introduction of altered management. After these peaks within each of the scenarios, the annual soil $\mathrm{C}$ accumulation effect persist over the course of the remaining simulation period, but with lower rates.

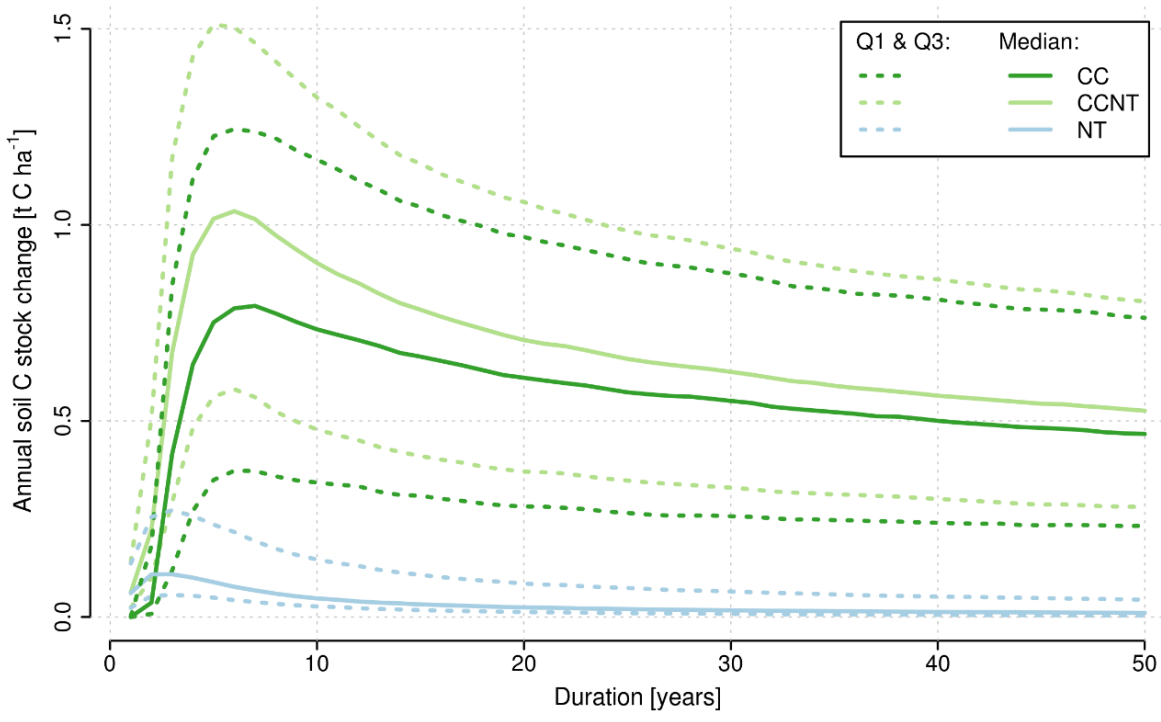

Figure 1. Area-weighted median across global cropland of average annual soil C sequestration rates (eq. 1) in $t$ $\mathrm{C} \mathrm{ha}^{-1} \mathrm{yr}^{-1}$ as solid lines and the first (Q1) and third (Q3) quartiles as dashed lines per alternative soil management scenario (CC: dark green, CCNT: light green, NT: light blue) compared to the baseline (REF) over the 50 year simulation period.

\subsection{Impacts of management type and duration on soil $\mathrm{N}$ and water dynamics}

All three alternative management scenarios exhibit higher transpiration but lower evaporation rates than found in the baseline (Fig. 2 a and b). In both cover crop simulations (CC and CCNT) the transpiration rates are higher because of the extended vegetative growth per cropland area unit compared to scenarios with the bare soil fallow during primary crop off-season periods (REF and NT). With CC, transpiration increased more strongly than evaporation was reduced, so that total evapotanspiration water fluxes were higher than in REF. In CCNT and NT, we found lowerded evaporation rates outweighing elevated transpiration rates compared to in REF with tillage. Cover crops in CC and CCNT led to lower but still positive median N net-mineralization rates (as the 
difference of soil $\mathrm{N}$ gross mineralization and immobilization rates) compared to bare soil fallowing practices in

REF and NT (Fig. 2 c). This decline is driven by larger increases of the soil N immobilization than of gross mineralization rates, especially within the first 10 years after introduction of cover crop practices (Fig S2.2). In both cover crop scenarios (CC and CCNT) N leaching rate shares of applied mineral N fertilizer were decreased faster and more strongly than in NT compared to in REF over the course of the simulation period (Fig. 2 d). After the first three initial years the response is stabilizing for all three alternative scenarios.
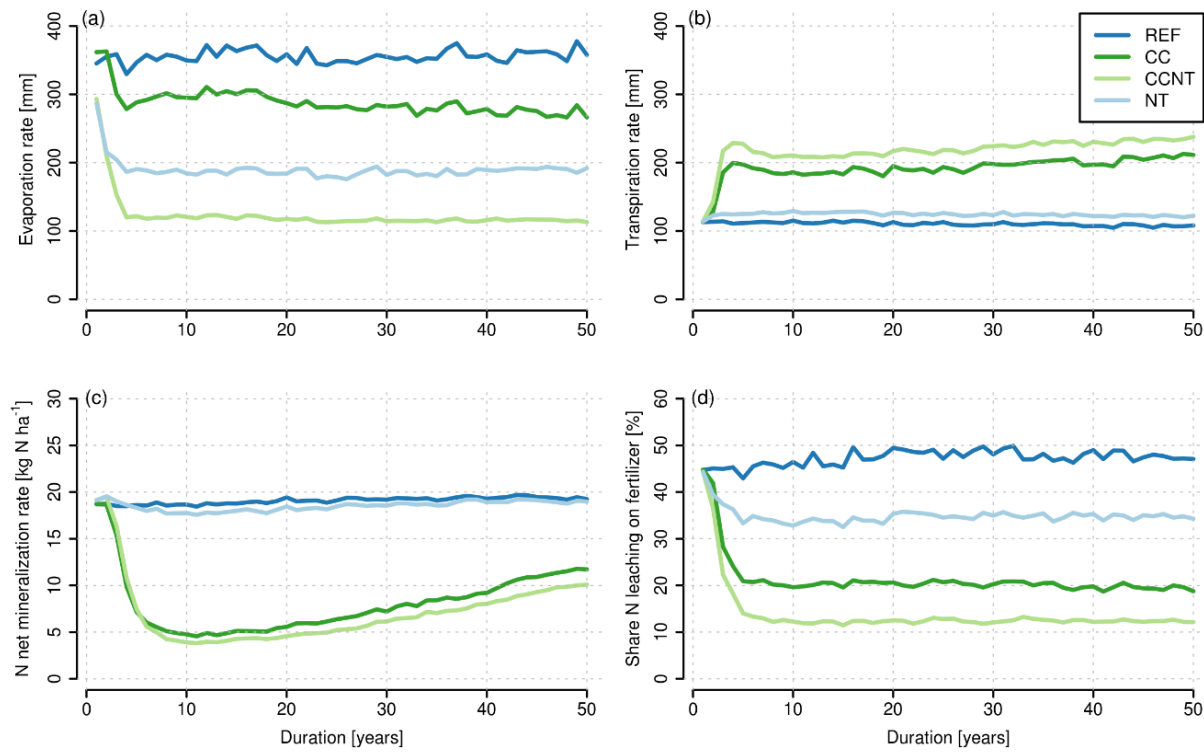

Figure 2. Plots in panel display the time-series for the 50 years simulation period of the annual global spatial aggregated area-weighted median per hectare cropland area as lines per management scenario (REF: dark blue, CC: dark green), CCNT: light green, and NT: light blue) for: (a) Evaporation rate in mm, (b) Transpiration rate in $\mathrm{mm}$, (c) Soil $\mathrm{N}$ net mineralization rate in $\mathrm{kg} \mathrm{N}^{-1}$ (derived as absolute difference between soil gross $\mathrm{N}$ mineralization and immobilization rates), and (d) Shares of annual soil $\mathrm{N}$ loss through leaching of applied mineral $\mathrm{N}$ fertilizer rate in percent (\%).

The relative differences in soil $\mathrm{N}$ leaching rates compared to the baseline (REF) are illustrated in Fig. 3 and indicate a reduction on the majority of global cropland in all three alternative soil management scenarios (for the respective spatial pattern see Fig. S2.3.2). Larger reductions and lower spatial variation are generally found during the last than during the first decades. Median reductions in $\mathrm{N}$ leaching rates in simulations including cover crops (CC and CCNT) were about two to three times higher than in NT. 


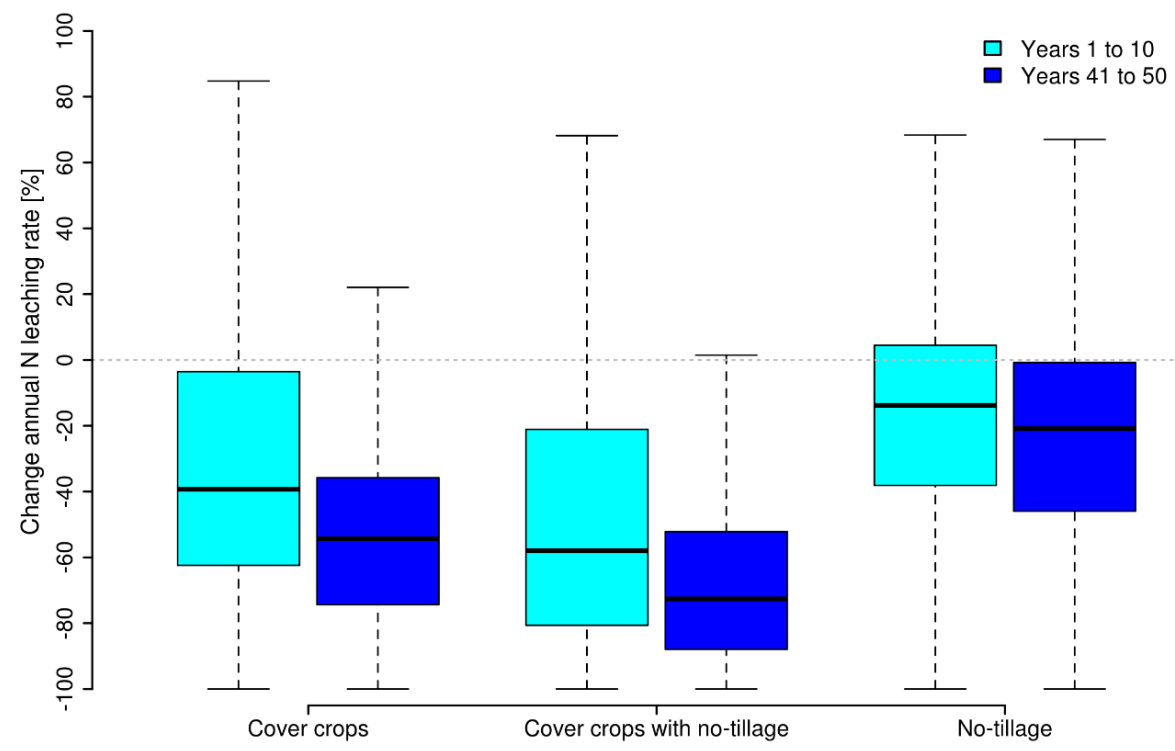

Figure 3. Boxplots of relative differences (\%) per hectare cropland area between annual $\mathrm{N}$ leaching rates in each of the simulated alternative management scenarios (CC, CCNT, and NT) compared to the baseline (REF) in the first (left bars, cyan) and last decades (right bars, blue) of the 50 year simulation period. The black midlines of boxes indicate the median responses per period, hinges of boxes show the first (Q1) and third (Q3) quartiles, and whiskers extend both to the minimum and maximum values within 1.5 times the interquartile range (IQR) of the distribution (outliers, defined as values outside this range are not shown here).

\subsection{Yield change of following main crop due to altered management and duration}

Whereas the impact of cover crop (CC) on main crop yield exhibited a quite consistent temporal pattern when analyzing per crop type (Table 1), the spatial variance was larger (Fig. 4). The productivity for maize and rice in northern cold and tropical humid climates is lowered with cover crops (CC), whereas drier temperate regions e.g., in the Western USA and Mediterranean reveal prominently enhanced yield effects for the four assessed crop types. 

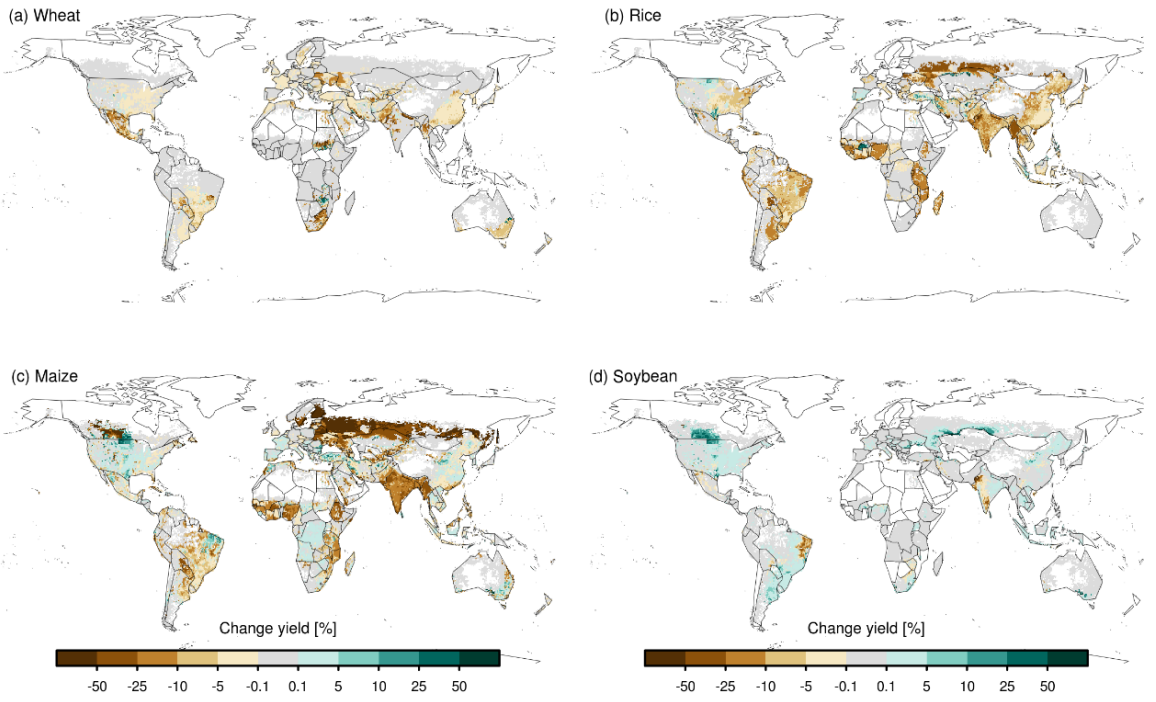

Figure 4. Maps showing changes of averaged rainfed and irrigated productivity in response to cover crops (CC) compared to bare fallow on cropland area during main crop off-season periods (REF) as annual median relative differences in percent (\%) per hectare of crop-specific cropland area and grid cell of the year 2010 for: (a) Wheat, (b) rice, (c) maize, and (d) soybean for the 50 year simulation period.

Comparing the changes across the management treatments, main crop productivity decreased most strongly in CC and increased most in NT relative to the baseline with tillage and bare soil fallow practices (REF) (Fig. 5 ad). In CC, rice yield declines were largest, whereas reduction for this crop type was halved on the majority of global cropland when combined with no-tillage practices (CCNT). In contrast to lowered maize yield in CC, we found positive median responses for this crop type in CCNT but with higher spatial variability of impact magnitude and direction. Wheat yield responses to any of the three alternative managements were very low in overall magnitude, being slightly reduced in both cover crop scenarios, but improved in NT. Soybean yield responded positively to all alternative management, around $9 \%$ higher median in CCNT and NT compared to in REF.

Exploring management impacts on productivity separated by water regimes revealed larger spatial variability of management responses for rainfed than for irrigated crop yields (Fig. S2.4). Soybeans in irrigated systems show no response to altered management practices. For the other crops, median yield responses to cover crop practices (CC, CCNT) were found to be either more negative or changing from a positive to a negative response in irrigated systems compared to rainfed systems. 

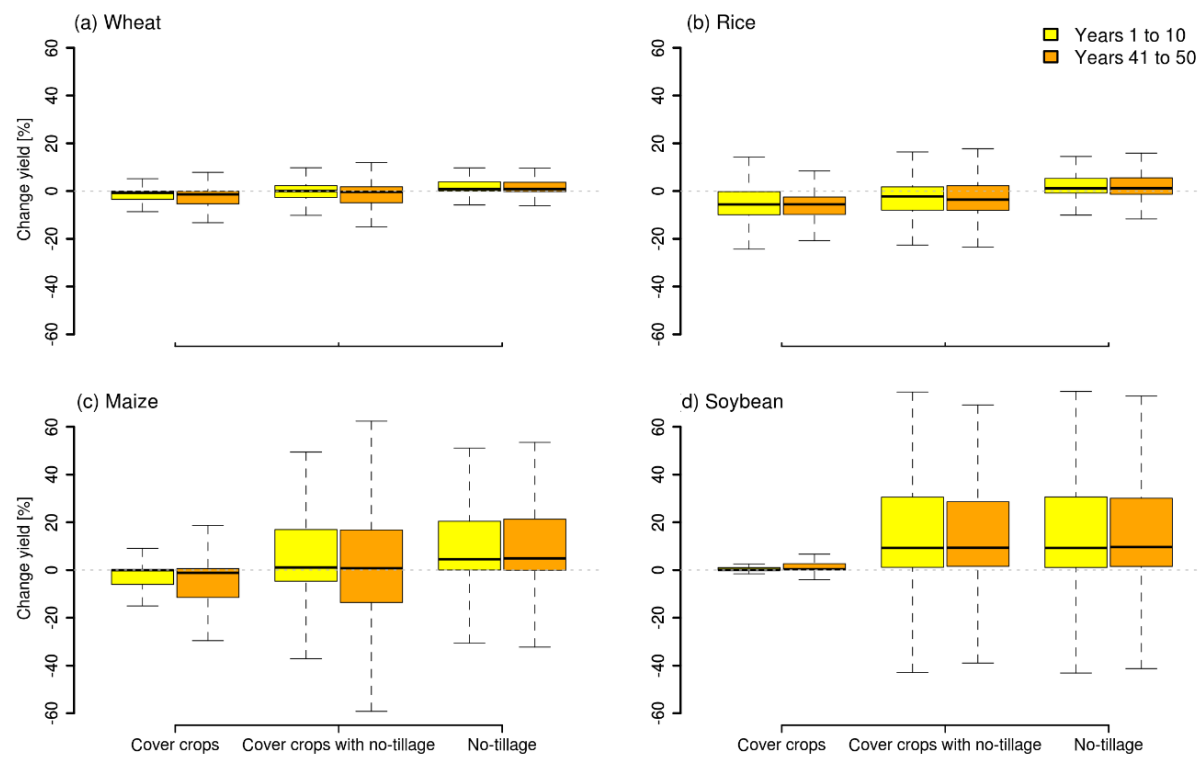

Figure 5. Panels (a-d) displaying changes in wheat, rice, maize, and soybean average yield as boxplots of relative differences in percent (\%) area-weighted by crop-specific physical cropland, due to alternative management practices (CC, CCNT, and NT) compared to the baseline (REF) for the first (left bars, yellow) and last decades (right bars, orange) of the 50 year simulation period. Boxes' black midlines indicate the spatial median across the distribution of responses, the lower and upper edges of the boxes the first and third quartiles, and whiskers extending both to the minimum and maximum values within 1.5 times the interquartile range, respectively from each Q1 and Q3 (outliers, defined as values outside this range are not shown here).

\subsection{Cover crop and no-tillage impacts on Conservation Agriculture cropland}

In response to cover crops applied with no-tillage practices (CCNT, Fig. S2.5), which we used as proxy for the full set of CA practices, positive yield changes dominate in areas of Conservation Agriculture (Fig. S1.4). Calculating median (quartiles) for yield changes on CA areas only, we found that the productivity for wheat, maize, and soybean was almost exclusively enhanced (6.4 (0.2, 29.4); 23.7 (3.3, 84.1); 27.8 (3.1, 79.0) \%, respectively). Although rice yield largely increased with the combined practices but can be lowered as well (5.6 (-3.1, 34.8) \%). Applying the CCNT change metrics for soil C (Fig. 1) to the temporal and spatial pattern of the mapped CA cropland time series data (Sect. S1.4), we estimated 1.4 PgC total historical soil C net-accumulation in the period 1974-2010. The area-weighted median (quartiles) of average annual soil C sequestration rate was $0.85(0.32,1.42) \mathrm{t} \mathrm{C} \mathrm{ha}^{-1} \mathrm{yr}^{-1}$ on CA areas. For the N leaching rate, we find a reduction by $-56.9(-80.4,-13.4) \%$ across global CA areas. 


\section{Discussion}

\subsection{Soil carbon sequestration}

The generated median soil C sequestration rates of cover crops were within the upper end of range of values reported in the literature (Table 1, Table S2.1). Few regions in temperate and dry climatic conditions, e.g. in Western USA, Turkey, Iraq, Iran, reveal a neutral or declining trend (S2.3). In line with findings of West and Six (2007), we found highest soil C sequestration potential in tropical regions (e.g. South-East Asia and Central Western Brazil), whereas Stockmann et al. (2013) derive largest potential for temperate humid regions. Abdalla et al. (2019) find both regions profiting from the practice, because there, water is a less limiting factor to biomass production and additional inputs produced by cover crops to the soil pools enhance soil C accumulation.

Assuming the median soil C sequestration rate of $0.55 \mathrm{t} \mathrm{C} \mathrm{ha}^{-1} \mathrm{yr}^{-1}$ during a period of 50 years for the estimated 400 million hectare cropland area potentially available annually for cover crop practices (Kaye and Quemada, 2017; Poeplau and Don, 2015), we estimated a global potential soil C sequestration rate of $0.22{\mathrm{PgC} \mathrm{yr}^{-1}}$ in the

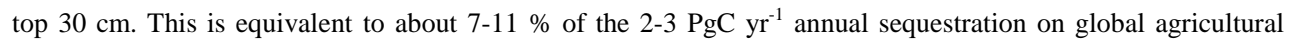
soils until the year 2030 targeted by the '4per1000' initiative (Minasny et al., 2017). However, our estimate is

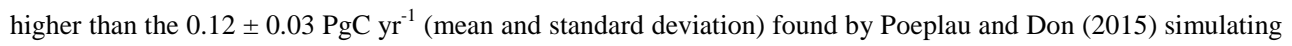
cover crops effects with the RothC model for a similar time frame but for $0-22 \mathrm{~cm}$ soil depth.

Lower annual median soil C sequestration rates with cover crops (CC) in the first three simulation years, reveal a time lag of response to altered management (Fig. 1). A similar effect is also apparent for $\mathrm{N}$ and water fluxes (Fig. 2). On the one hand, this may be because cover crops are first established at the end of the first main crop growing season, so that the full effect becomes visible in the second year only. On the other hand, a temporal delay of detectable cover crop impacts on soil organic $\mathrm{C}$ concentration within the first years of practice was also found in the review of ecosystem services of cover crop practices by Blanco-Canqui et al. (2015), due to the complexity of biophysical processes affected by changes in biomass inputs due to altered management practices. This suggests that cover crops need to be cultivated for at least three years to take effect. Duration, as the number of years a system has been under a management practice, was also identified as one of the most important factors to reap the benefits of altered soil physical properties from cover crops practices (Laborde et al., 2020; Nouri et al., 2020; West and Six, 2007).

The higher soil C sequestration rates calculated for the first than for the last decade of the 50 year simulation period (Table 1, Fig. 1) are in line with other studies' estimates as well. For example Sommer and Bossio (2014), assumed their soil $\mathrm{C}$ sequestration rate functions for their simulations of cover crop impacts to peak between the third and seventh year of continuous practice and then to level off after about 20 to 40 years. Corsi et al. (2012) in their meta-analysis on effects of CA practices, found a decreasing rate of soil C sequestration between the fifth and twentieth years. The decreased change rates towards the end of the 50 year simulation period, suggest a saturation effect (for cover crops later than for no-tillage), when soil $\mathrm{C}$ and $\mathrm{N}$ pools approach a new equilibrium state, as discussed by Kaye and Quemada (2017); Poeplau and Don (2015); Smith (2016). However, the new equilibrium of soil C (Corbeels et al., 2018; Poeplau and Don, 2015) is not reached in our simulations for the majority of global cropland for CC or CCNT within the analyzed 50 years simulation period. For NT, half of global cropland reached the new equilibrium after 12 years.

The median soil C sequestration rate for both cover crop scenarios (CC and CCNT) were higher than for notillage (NT), which is in line with the review of Kaye and Quemada (2017). The effect of combined cover crop 
and no-tillage practices (CCNT) exhibited the largest soil C sequestration rate with median $0.72 \mathrm{t} \mathrm{C} \mathrm{ha}^{-1} \mathrm{yr}^{-1}$ in the first decade. Our result were higher than Franzluebbers (2010) finding a soil C sequestration rate of $0.45 \pm$ $0.04 \mathrm{t} \mathrm{C} \mathrm{ha}^{-1} \mathrm{yr}^{-1}$ for experiments comparing cover crops combined with tillage and no-tillage in Southeast USA for about 11 years and were within the range stated in the meta-analysis of experiments from Brazil (0.4-1.9 t C $\mathrm{ha}^{-1} \mathrm{yr}^{-1}$ ) and France (0.1-0.4 t C ha ${ }^{-1} \mathrm{yr}^{-1}$ ) (Scopel et al., 2013) for experiments with a duration of 5-28 years. The higher effect of combined cover crops and no-tillage on soil C stock is also supported by Corbeels et al. (2018) finding higher soil C stocks in case of CA compared to conventionally tilled systems, whereas Abdalla et al. (2019) and Poeplau and Don (2015), find no significant differences due to changed tillage practices with cover crops in their meta-analyses.

\subsection{Nitrogen leaching}

The derived $\mathrm{N}$ leaching rate reduction in CC were at the upper end of the -70 to -50 - \% range of effects reported in literature (Table 1, Table S2.1). For the spatial effects of cover crops, it can be depicted, that most cropland can profit from about halved $\mathrm{N}$ leaching rates (Fig. 3, Fig. S2.3.2). One important driver of the size of the effect of cover crops is the length of the fallow season. In northern regions, main crop growing seasons are rather short and aligned across crop types, so that a lot of off-season cropland area is available for cover crops for relatively longer time. Largest $\mathrm{N}$ leaching rate reduction can be found in cold temperate regions (such as in Russia) and humid tropics (e.g., large parts in Africa), where external $\mathrm{N}$ inputs (i.e. mineral $\mathrm{N}$ fertilizer rates, also see Sect. S1.2 for rates used here) are rather low. On the one hand, the variance of cover crop effects across global cropland can be attributed to management intensity (e.g., fertilizer application rates), in this study prominently seen as differences at some national borders (USA and Canada). According to Wittwer et al. (2017) efficiency of cover crops to reduce $\mathrm{N}$ leaching is decreasing with management intensity (including fertilizer application rates and tillage practices). On the other hand, the spatial variance of cover crop effects within countries suggest differences due to soil and climatic conditions. Only few drier regions reveal either a neutral response or slight increase of $\mathrm{N}$ leaching rates due to cover crops (Fig. S2.3.2). This can be attributed to reduced growth of cover crops, limiting their capacity for $\mathrm{N}$ uptake of excess $\mathrm{N}$ remaining in the soil column after harvest of the main crop.

Because the plant material from cover crops that drives the $\mathrm{C}$ sequestration with the practices (Sect. 3.1, 4.1) has a wider $\mathrm{C}$ to $\mathrm{N}$ ratio than the soils, it leads to stronger immobilization of mineral $\mathrm{N}$ in the soil column (Fig. S2.2). Increased evapotranspiration and immobilization but also uptake of $\mathrm{N}$ by cover crop plants were found to reduce the soil N (Quemada et al., 2013; Thapa et al., 2018; Zhu et al., 2012), which would be susceptible to leaching from cropland soils during primary crop off-season periods (Abdalla et al., 2019; Alonso-Ayuso et al., 2014; Delgado et al., 2007; Tonitto et al., 2006). For their efficiency in $\mathrm{N}$ uptake, grass cover crop are also described as 'scavengers' (Blanco-Canqui et al., 2015). Therefore, cover crops can be regarded especially suitable for high-input farming systems, where surplus $\mathrm{N}$ left in the soil after harvest of the main crop, can be retained in the biomass of the cover crop. After termination, the $\mathrm{C}$ and $\mathrm{N}$ contained in the cover crops biomass, can serve as 'green manure' temporally fixed in compounds of the soil organic matter (Zomer et al., 2017). 


\subsection{Crop yields}

The average yield change computed for cover crops (CC) were at the lower end of the range -5 to $11.6 \%$ of values found in literature (Table 1, S2.1). Reduced productivity levels of the following main crop are reported mostly in the context of competition with the cover crops for water and nutrients (Abdalla et al., 2019; Tonitto et al., 2006; Valkama et al., 2015). The increased immobilization of soil $\mathrm{N}$ after the introduction of cover crops is thought to actually exacerbate N stress (Abdalla et al., 2019; Erenstein, 2003; Kuo and Sainju, 1998; Ranaivoson et al., 2019). Marcillo and Miguez (2017) assume that lower maize yields found with cover crops may also be caused by a temporal asynchrony between periods of soil $\mathrm{N}$ mineralization and high $\mathrm{N}$ demand of the main crop. Several authors (Marcillo and Miguez, 2017; Thapa et al., 2018; Tonitto et al., 2006) report no significant effects of non-leguminous cover crop species on yields of the subsequent main crop, which may be caused by the mainly intensively fertilized experiments considered, e.g. in Tonitto et al. (2006). This is in line with our findings for soybean, which is an $\mathrm{N}$ fixer (not subject to $\mathrm{N}$ limitations in LPJmL) and sees hardly any yield penalty from cover crops. Also, the mostly negative responses to cover crops for the three cereal crop types in irrigated systems (Fig. S2.4.2), where water is not a growth-limiting factor for the main crop, can only be explained by a decrease in N availability for the main crop. Several authors (Marcillo and Miguez, 2017; Thapa et al., 2018; Tonitto et al., 2006) report no significant effects of non-leguminous cover crop species on yields of the subsequent main crop, which may be caused by the mainly intensively fertilized experiments considered, e.g. in Tonitto et al. (2006).

Cover crops affect soil water in different ways: cover crops tend to increase transpiration (see Fig. 2 b), but at the same time reduce soil evaporation (Fig. 2 a) and increase infiltration (Dabney et al., 2001). Depending on the relative magnitude of these processes, soil water availability for the main crop can increase or decrease at different locations. This is clearly shown in Fig. S2.4, where yield responses to cover crops in rainfed systems reveal a much larger variability than in irrigated systems. The spatial variability of yield response to cover crops for different crops (Fig. 4 and 5) is the result of differences in how cover crops impact water availability of the main crop, how water limited the main crop is, and how strongly the cover crop the reduces $\mathrm{N}$ availability for the main crop. However, sensitivity to changes in water availability is highest in rainfed systems in water limited environments, on soil types of low soil water holding capacity, or insufficient recharge, which limits their applicability under such conditions (Marcillo and Miguez, 2017).

In contrast to CC, an enhancing effect on productivity was found with NT for all four crop types. Also Su et al. (2021) find for wheat, maize, and soybean, that although no-tillage could lead to yield declines in cooler and wetter regions, this loss to be more than compensated at the global scale by increased productivity in arid rainfed cropping areas. In our model, the yield increase can mainly be attributed to the water-saving effects simulated with no-tillage compared to both REF and CC scenarios with conventional tillage (Fig. 2, Fig. 5). This is caused by the built up of a litter layer due to no-tillage practices covering the soil as mulch, which increases infiltration rates as well as reduces evaporation and surface runoff rates (Jägermeyr et al., 2016; Lutz et al., 2019).

In CCNT, the effects of cover cops and no-tillage are combined, so that cover crops provide vegetative soil cover on cropland during main crop off-season, and when terminated serve as additional mulching material during the following main crop growing periods. This additional mulch layer in combination with no-tillage counteract the higher transpiration from cover crops by improving infiltration and reducing evaporation (Abdalla et al., 2019; Scopel et al., 2013). Enhanced maize and soybean yields, as well as less rice yield reductions found with CCNT 
than with CC compared to REF, reveal co-benefits of both practices (Fig. 5). The assumption of synergetic

effects of both practices in CCNT were supported by the even higher median yield responses derived here for cropland with Conservation Agriculture practices (Sect 3.5, Fig. S2.5), which area was mapped with a higher likelihood to arid regions (Porwollik et al., 2019).

The here presented yield responses to different management settings (NT, CCNT) are only partly in line with findings of Pittelkow et al. (2015), analyzing experiments lasting 1-31 years, who find largest declines (-9.9 \%) when no-tillage was adopted alone and decreased negative effects (-6.2 \%) when no-tillage was applied with crop rotation. However, cover crops as modelled in our CCNT scenario are only one aspect of crop rotation enhancement considered in the analyses by Pittelkow et al. (2015), which limits the comparability between our and their findings.

\subsection{Methodological limitations and implications}

The results indicate in general reliability of the here used model version LPJml5.0-tillag-cc to reproduce ranges of reported temporal and spatial pattern, magnitude, as well as the sign of direction of cover crop impacts at the global scale (Table 1). However, aggregated changes due to CC presented here were not always matching other studies' findings (Table S2.1).

On the one hand, these deviations may result from different soil depth considered or meta-analyses reporting averages across different years and experiments (Nyawira et al., 2016). Further uncertainties are related to literature values, which may include experiment results from measurements during the main crop growing season only instead of covering the entire year (Quemada et al., 2013). On the other hand, important processes that determine the effect of cover crops in field trials, such as erosion, weeds, pests, or diseases, are not accounted for in this model version.

The high C sequestration rates calculated for CC, e.g. in the humid tropics (Fig. S2.3.1) may be due to an overestimation of the simulated fallow period length for cropland in this climatic region. In the model version used here, only the main representative growing season of a crop is simulated per year, so that multiple cropping practices for areas where several crop harvests per year are common (Siebert et al., 2010; Waha et al., 2020) are not well covered, resulting in distorted cover crop productivity levels and biomass input to the soil pools. The here applied model setting for the representation of irrigated cropland in the simulations, assuming unlimited water availability for irrigation practices, may cause an overestimation of main crop productivity as well as resulting main crop residue input amounts to the soil pools. The computed initial soil C pools do not represent the conditions on current croplands because our simulations excluded historical land use dynamics, to which responses in soil usually are slow and of long-term (Nyawira et al., 2016). Pugh et al. (2015) find, that the soil legacy flux from land use and landcover change may dominate ecosystem carbon losses for a timescale up to a century. By starting the simulations from soil C pools in equilibrium, we aimed to make sure that the acquired response is due to altered management. The deviations in initial soil $\mathrm{C}$ and $\mathrm{N}$ pools was accounted for in this study by presenting responses to alternative management scenarios (CC, CCNT, NT) in relation to the baseline scenario (REF).

The potential trade-off between environmental benefits (reduced $\mathrm{N}$ leaching, soil carbon sequestration) and main crop productivity changes found here with cover crops and conventional tillage practices, suggest the requirement for the complementary modification of fertilizer management and the parallel adoption of irrigation 
or soil water preserving practices, such as no-tillage and mulching practices to maintain current main crop yield levels. Further global scale investigation of complementary land management practices may include leguminous (N fixing) cover crop species or mixes of them with the here presented grass type. Production costs associated to additional seed purchase for cover cropping (Alonso-Ayuso et al., 2020), and opportunity cost for field activities of the farmer in otherwise off-season periods (Lee and Thierfelder, 2017), need to be evaluated in integrated assessments against the environmental benefits from the practice (Blanco-Canqui et al., 2015). Further studies are needed for the quantification of cover crop impacts with climate change and to explore options for adaptation of the practice to regionally specific environmental and economic conditions, influencing farming decisions and land management practices.

\section{Conclusion}

This study presents the first global temporal and spatially explicit quantification of impacts of cover crops in combination with tillage practices. The routines of cover crops implemented into LPJmL, allow for consistent, global-scale assessments of biophysical, biogeochemical, and agronomic effects, such as on mapped CA cropland during the period 1974 to 2010 and for exploring potentials of sustainable cropland management practices.

We found, that cover crops enable soil C sequestration and reduce $\mathrm{N}$ losses through leaching on the majority of global cropland, except in few and mostly unproductive arid regions. Cover crop with conventional tillage practices increase evapotranspiration fluxes and decrease soil $\mathrm{N}$ net-mineralization rates compared to bare soil fallowing practices by lowering plant available soil water and nitrogen, leading to reduced growth and yield of the following main crop. Declining yield effects due to cover crops were found for rice, but also for maize, and wheat, most pronounced for cropping areas in northern cold climatic regions. Enhanced productivities with cover crops and tillage for these three staple crops were depicted for temperate regions with high mineral $\mathrm{N}$ fertilizer application rates and almost all soybean production.

The yield responses to altered management generated for all four crop types were rather constant over time, whereas for changes in soil $\mathrm{N}$ leaching rate and $\mathrm{C}$ sequestration pronounced temporal dynamics were found. For soil $\mathrm{C}$ sequestration and $\mathrm{N}$ leaching the sign of changes was mostly homogeneous across global cropland, whereas for productivity, the direction and magnitude of changes vary considerably among crop types and for different world regions.

For cover crops applied with no-tillage (CCNT), both the soil $\mathrm{C}$ sequestration rate and the reduction of $\mathrm{N}$ leaching were largest. The combined practices take advantage of the additional biomass production by cover crops and of the soil water saving effects associated to no-tillage, which results in increasing inputs to the soil, improved nutrient cycling, and substantially reduced rainfed crop yield penalties. We resume from the findings, that the heterogeneity of cover crop impacts on $\mathrm{C}, \mathrm{N}$, and water processes are determined by the primary crop type cultivated, water regime (rainfed or irrigated), tillage and mulching practices, location, as well as management duration. This study's results demonstrate the potential role of cover crop practices as a nature based solution (Keestra et al., 2018) to transform croplands to C sinks for climate change mitigation. 
https://doi.org/10.5194/bg-2021-215

Preprint. Discussion started: 1 September 2021

(c) Author(s) 2021. CC BY 4.0 License.

Code and data availability. The LPJml5.0-tillage-cc model code version, model output data, and R-scripts used repository: https://doi.org/10.5281/zenodo.5178070 (Porwollik et al., 2021).

Supplement link. The supplement related to this article is available online at:

Author contributions. VP, CM, SR, and JH designed the research. VP and CM implemented the cover crops code functionalities with the support of all other authors. VP generated the CA cropland data set and conducted the simulations. VP and CM analyzed results. VP prepared the manuscript and all co-authors contributed by commenting and editing.

Competing interests. The authors declare that they have no conflict of interest.

Acknowledgements. We thank Tobias Herzfeld for support in model code development, Kristine Karstens for constructive discussions on cropland soil carbon, as well as Jan Kowalewski and Jannes Breier for data processing contributions.

Financial Support. SR and VP acknowledge financial support throughout the MACMIT (01LN1317A), SR also from the CLIMASTEPPE (01DJ18012) and JH from the EXIMO (01LP1903D) projects, all funded through the German Federal Ministry of Education and Research (BMBF). 


\section{References}

Abdalla, M., Hastings, A., Cheng, K., Yue, Q., Chadwick, D., Espenberg, M., Truu, J., Rees, R. M., and Smith, P.: A critical review of the impacts of cover crops on nitrogen leaching, net greenhouse gas balance and crop productivity, Global Change Biology, 25, 2530- 2543, doi: https://doi.org/10.1111/gcb.14644, 2019.

Alexander, P., Brown, C., Arneth, A., Finnigan, J., Moran, D., and Rounsevell, M. D. A.: Losses, inefficiencies and waste in the global food system, Agricultural Systems, 153, 190-200, doi: https://doi.org/10.1016/j.agsy.2017.01.014, 2017.

Alonso-Ayuso, M., Gabriel, J. L., Hontoria, C., Ibáñez, M. Á., and Quemada, M.: The cover crop termination choice to designing sustainable cropping systems, European Journal of Agronomy;, 114, 126000, doi: https://doi.org/10.1016/j.eja.2020.126000, 2020.

Alonso-Ayuso, M., Gabriel, J. L., and Quemada, M.: The kill date as a management tool for cover cropping success, PLOS ONE, 9, e109587, doi: https://doi.org/10.1371/journal.pone.0109587, 2014.

Blanco-Canqui, H., Shaver, T. M., Lindquist, J. L., Shapiro, C. A., Elmore, R. W., Francis, C. A., and Hergert, G. W.: Cover Crops and Ecosystem Services: Insights from Studies in Temperate Soils, Agronomy Journal, 107, 2449-2474, doi: https://doi.org/10.2134/agronj15.0086, 2015.

Bodirsky, B. L., Rolinski, S., Biewald, A., Weindl, I., Popp, A., and Lotze-Campen, H.: Global Food

Demand Scenarios for the 21st Century, PLOS ONE, 10, e0139201, doi: https://doi.org/10.1371/journal.pone.0139201, 2015.

Bondeau, A., Smith, P. C., Zaehle, S., Schaphoff, S., Lucht, W., Cramer, W., Gerten, D., LotzeCampen, H., Müller, C., Reichstein, M., and Smith, B.: Modelling the role of agriculture for the 20th century global terrestrial carbon balance, Global Change Biology, 13, 679-706, doi: https://doi.org/10.1111/j.1365-2486.2006.01305.x, 2007.

Corbeels, M., Cardinael, R., Naudin, K., Guibert, H., and Torquebiau, E.: The 4 per 1000 goal and soil carbon storage under agroforestry and conservation agriculture systems in sub-Saharan Africa, Soil and Tillage Research, doi: https://doi.org/10.1016/j.still.2018.02.015, 2018.

Corsi, S., Friedrich, T., Kassam, A., Pisante, M., and Sà, J. d. M.: Soil organic carbon accumulation and greenhouse gas emission reductions from conservation agriculture: A literature review, FAO, 2012.

Dabney, S. M., Delgado, J. A., Meisinger, J. J., Schomberg, H. H., Liebig, M. A., Kaspar, T., Mitchell, J., and Reeves, W.: Using cover crops and cropping systems for nitrogen management. In: Advances in Nitrogen Management, USDA Agricultural Research Service, 2011.

Dabney, S. M., Delgado, J. A., and Reeves, D. W.: Using winter cover crops to improve soil and water quality, Communications in Soil Science and Plant Analysis, 32, 1221-1250, doi: https://doi.org/10.1081/CSS-100104110, 2001. 
Delgado, J. A., Dillon, M. A., Sparks, R. T., and Essah, S. Y.: A decade of advances in cover crops, Journal of Soil and Water Conservation, 62, 110A-117A, 2007.

Erenstein, O.: Smallholder conservation farming in the tropics and sub-tropics: a guide to the development and dissemination of mulching with crop residues and cover crops, Agriculture, Ecosystems and Environment, 100, 17-37, doi: https://doi.org/10.1016/S0167-8809(03)00150-6, 2003. EUROSTAT: Agri-environmental indicator - soil cover. In: Fact sheet, Statistics explained, date accessed: 05/04/2016, 2018.

FAO: Conservation Agriculture. AQUASTAT Main Database Food and Agriculture Organization of the United Nations (FAO), 2016.

Florentín, M. A., Peñalva, M., Calegari, A., and Derpsch, R.: Greeen manure/cover crops and crop rotation in Conservation Agriculture on small farms, Food and Agriculture Organisation of the United Nation (FAO), Rome, 2011.

Forkel, M., Carvalhais, N., Schaphoff, S., v. Bloh, W., Migliavacca, M., Thurner, M., and Thonicke, K.: Identifying environmental controls on vegetation greenness phenology through model-data integration, Biogeosciences, 11, 7025-7050, doi: https://doi.org/10.5194/bg-11-7025-2014, 2014.

Friedlingstein, P., O'Sullivan, M., Jones, M. W., Andrew, R. M., Hauck, J., Olsen, A., Peters, G. P., Peters, W., Pongratz, J., Sitch, S., Le Quéré, C., Canadell, J. G., Ciais, P., Jackson, R. B., Alin, S., Aragão, L. E. O. C., Arneth, A., Arora, V., Bates, N. R., Becker, M., Benoit-Cattin, A., Bittig, H. C., Bopp, L., Bultan, S., Chandra, N., Chevallier, F., Chini, L. P., Evans, W., Florentie, L., Forster, P. M., Gasser, T., Gehlen, M., Gilfillan, D., Gkritzalis, T., Gregor, L., Gruber, N., Harris, I., Hartung, K., Haverd, V., Houghton, R. A., Ilyina, T., Jain, A. K., Joetzjer, E., Kadono, K., Kato, E., Kitidis, V., Korsbakken, J. I., Landschützer, P., Lefèvre, N., Lenton, A., Lienert, S., Liu, Z., Lombardozzi, D., Marland, G., Metzl, N., Munro, D. R., Nabel, J. E. M. S., Nakaoka, S. I., Niwa, Y., O'Brien, K., Ono, T., Palmer, P. I., Pierrot, D., Poulter, B., Resplandy, L., Robertson, E., Rödenbeck, C., Schwinger, J., Séférian, R., Skjelvan, I., Smith, A. J. P., Sutton, A. J., Tanhua, T., Tans, P. P., Tian, H., Tilbrook, B., van der Werf, G., Vuichard, N., Walker, A. P., Wanninkhof, R., Watson, A. J., Willis, D., Wiltshire, A. J., Yuan, W., Yue, X., and Zaehle, S.: Global Carbon Budget 2020, Earth System Science Data, 12, 3269-3340, doi: https://doi.org/10.5194/essd-12-3269-2020, 2020.

Godfray, H. C. J., Beddington, J. R., Crute, I. R., Haddad, L., Lawrence, D., Muir, J. F., Pretty, J., Robinson, S., Thomas, S. M., and Toulmin, C.: Food Security: The Challenge of Feeding 9 Billion People, Science, 327, 812-818, doi: 10.1126/science.1185383, 2010.

Gonzalez-Sanchez, E. J., Veroz-Gonzalez, O., Conway, G., Moreno-Garcia, M., Kassam, A., Mkomwa, S., Ordoñez-Fernandez, R., Triviño-Tarradas, P., and Carbonell-Bojollo, R.: Meta-analysis on carbon sequestration through Conservation Agriculture in Africa, Soil and Tillage Research, 190, 22-30, doi: https://doi.org/10.1016/j.still.2019.02.020, 2019.

Handcock, M. S.: Relative Distribution Methods. Version 1.6-6. https://CRAN.Rproject.org/package=reldist. 2016. 
https://doi.org/10.5194/bg-2021-215

Preprint. Discussion started: 1 September 2021

(c) Author(s) 2021. CC BY 4.0 License.

Herzfeld, T., Heinke, J., Rolinski, S., and Müller, C.: SOC sequestration potentials for agricultural management practices under climate change, Earth System Dynamics Discuss. [preprint], 2021, 1-27, doi: https://doi.org/10.5194/esd-2021-35, 2021.

Hijmans, R. J. and van Etten, J.: Raster: Geographic analysis and modeling with raster data. 2012. Japan, 1-36 pp., 2006.

Jägermeyr, J., Gerten, D., Schaphoff, S., Heinke, J., Lucht, W., and Rockström, J.: Integrated crop water management might sustainably halve the global food gap, Environmental Research Letters, 11, 025002, doi: https://doi.org/10.1088/1748-9326/11/2/025002, 2016.

Jian, J., Du, X., Reiter, M. S., and Stewart, R. D.: A meta-analysis of global cropland soil carbon changes due to cover cropping, Soil Biology and Biochemistry, 143, 107735, doi: https://doi.org/10.1016/j.soilbio.2020.107735, 2020.

Kassam, A., Friedrich, T., and Derpsch, R.: Global spread of Conservation Agriculture, International Journal of Environmental Studies, 76, 29-51, doi: https://doi.org/10.1080/00207233.2018.1494927, 2019.

Kaye, J. P. and Quemada, M.: Using cover crops to mitigate and adapt to climate change. A review, Agron. Sustain. Dev., 37, 4, doi: https://doi.org/10.1007/s13593-016-0410-x, 2017.

Keestra, S., Nunes, J., Novara, A., Finger, D., and Avelar, D.: The superior effect of nature based solutions in land management for enhancing ecosystem services, Science of the Total Environment, 610, 997-1009, doi: https://doi.org/10.1016/j.scitotenv.2017.08.077, 2018.

Kollas, C., Kersebaum, K. C., Nendel, C., Manevski, K., Müller, C., Palosuo, T., Armas-Herrera, C. M., Beaudoin, N., Bindi, M., Charfeddine, M., Conradt, T., Constantin, J., Eitzinger, J., Ewert, F., Ferrise, R., Gaiser, T., Cortazar-Atauri, I. G. d., Giglio, L., Hlavinka, P., Hoffmann, H., Hoffmann, M. P., Launay, M., Manderscheid, R., Mary, B., Mirschel, W., Moriondo, M., Olesen, J. E., Öztürk, I., Pacholski, A., Ripoche-Wachter, D., Roggero, P. P., Roncossek, S., Rötter, R. P., Ruget, F., Sharif, B., Trnka, M., Ventrella, D., Waha, K., Wegehenkel, M., Weigel, H.-J., and Wu, L.: Crop rotation modelling - A European model intercomparison, European Journal of Agronomy, 70, 98-111, doi: http://dx.doi.org/10.1016/j.eja.2015.06.007, 2015.

Kowalewski, J.: The performance assessment of vegetation models - Demonstration of a benchmarking system application Master of Science (Geographical Information Science \& Systems) Master Thesis, Interfakultärer Fachbereich für GeoInformatik (Z_GIS), Paris Lodron-Universität Salzburg, 2016.

Kuo, S. and Sainju, U. M.: Nitrogen mineralization and availability of mixed leguminous and nonleguminous cover crop residues in soil, Biology and Fertility of Soils, 26, 346-353, 1998.

10 Laborde, J. P., Wortmann, C. S., Blanco-Canqui, H., Baigorria, G. A., and Lindquist, J. L.: Identifying the drivers and predicting the outcome of conservation agriculture globally, Agricultural Systems, 177, 102692, doi: https://doi.org/10.1016/j.agsy.2019.102692, 2020. 
https://doi.org/10.5194/bg-2021-215

Preprint. Discussion started: 1 September 2021

(c) Author(s) 2021. CC BY 4.0 License.

Lal, R.: Carbon emission from farm operations, Environment International, 30, 981-990, doi: https://doi.org/10.1016/j.envint.2004.03.005, 2004a.

Lal, R.: Soil Carbon Sequestration Impacts on Global Climate Change and Food Security, Science, 304, 1623-1627, doi: https://doi.org/10.1126/science.1097396, 2004b.

Lee, N. and Thierfelder, C.: Weed control under conservation agriculture in dryland smallholder farming systems of southern Africa. A review, Agronomy for Sustainable Development., 37, 48, doi: https://doi.org/10.1007/s13593-017-0453-7, 2017.

Lutz, F., Herzfeld, T., Heinke, J., Rolinski, S., Schaphoff, S., Von Bloh, W., Stoorvogel, J., and Müller, C.: Simulating the effect of tillage practices with the global ecosystem model LPJmL (version 5.0-tillage), Geoscientific Model Development, 12, 2419-2440, doi: https://doi.org/10.5194/gmd-122419-2019, 2019.

Marcillo, G. S. and Miguez, F.: Corn yield response to winter cover crops: An updated meta-analysis, Journal of Soil and Water Conservation, 72, 226-239, doi: https://doi.org/10.2489/jswc.72.3.226, 2017.

Minasny, B., Malone, B. P., McBratney, A. B., Angers, D. A., Arrouays, D., Chambers, A., Chaplot, V., Chen, Z.-S., Cheng, K., Das, B. S., Field, D. J., Gimona, A., Hedley, C. B., Hong, S. Y., Mandal, B., Marchant, B. P., Martin, M., McConkey, B. G., Mulder, V. L., O'Rourke, S., Richer-de-Forges, A. C., Odeh, I., Padarian, J., Paustian, K., Pan, G., Poggio, L., Savin, I., Stolbovoy, V., Stockmann, U., Sulaeman, Y., Tsui, C.-C., Vågen, T.-G., van Wesemael, B., and Winowiecki, L.: Soil carbon 4 per mille, Geoderma, 292, 59-86, doi: http://dx.doi.org/10.1016/j.geoderma.2017.01.002, 2017.

Nouri, A., Lee, J., Yoder, D. C., Jagadamma, S., Walker, F. R., Yin, X., and Arelli, P.: Management duration controls the synergistic effect of tillage, cover crop, and nitrogen rate on cotton yield and yield stability, Agriculture, Ecosystems and Environment, 301, 107007, doi: https://doi.org/10.1016/j.agee.2020.107007, 2020.

Nyawira, S. S., Nabel, J. E. M. S., Don, A., Brovkin, V., and Pongratz, J.: Soil carbon response to land-use change: evaluation of a global vegetation model using observational meta-analyses, Biogeosciences, 13, 5661-5675, doi: https://doi.org/10.5194/bg-13-5661-2016, 2016.

640 Olin, S., Lindeskog, M., Pugh, T. A. M., Schurgers, G., Wårlind, D., Mishurov, M., Zaehle, S., Stocker, B. D., Smith, B., and Arneth, A.: Soil carbon management in large-scale Earth system modelling: implications for crop yields and nitrogen leaching, Earth System Dynamics, 6, 745-768, doi: https://doi.org/10.5194/esd-6-745-2015, 2015.

Paulsen, H. M.: Inventory of techniques for carbon sequestration in agricultural soils, Chapter 2. Interreg North Sea Region, Thünen-Institute of Organic Farming, Germany, 2020.

Pierce, D.: Interface to Unidata netCDF (Version 4 or Earlier) Format Data Files., 2015.

Pittelkow, C. M., Liang, X., Linquist, B. A., van Groenigen, K. J., Lee, J., Lundy, M. E., van Gestel, N., Six, J., Venterea, R. T., and van Kessel, C.: Productivity limits and potentials of the principles of conservation agriculture, Nature, 517, 365-368, doi: https://doi.org/10.1038/nature13809, 2015. 
https://doi.org/10.5194/bg-2021-215

Preprint. Discussion started: 1 September 2021

(c) Author(s) 2021. CC BY 4.0 License.

Poeplau, C. and Don, A.: Carbon sequestration in agricultural soils via cultivation of cover crops - A meta-analysis, Agriculture, Ecosystems and Environment, 200, 33-41, doi: https://doi.org/10.1016/j.agee.2014.10.024, 2015.

Porwollik, V., Rolinski, S., Heinke, J., and Müller, C.: Generating a rule-based global gridded tillage dataset, Earth System Science Data, 11, 823-843, doi: https://doi.org/10.5194/essd-11-823-2019, 2019. Porwollik, V., Rolinski, S., Heinke, J., von Bloh, W., Schaphoff, S., Herzfeld, T., and Müller, C.: LPJmL5.0-tillage-cc model source code, management simulation outputs, and $\mathrm{R}$ script for postprocessing data (1.0.1). Zenodo, doi: https://doi.org/10.5281/zenodo.5178070, 2021.

Pugh, T. A. M., Arneth, A., Olin, S., Ahlström, A., Bayer, A. D., Klein Goldewijk, K., Lindeskog, M., and Schurgers, G.: Simulated carbon emissions from land-use change are substantially enhanced by accounting for agricultural management, Environmental Research Letters, 10, 124008, doi: https://doi.org/10.1088/1748-9326/10/12/124008, 2015.

Quemada, M., Baranski, M., Nobel-de Lange, M. N. J., Vallejo, A., and Cooper, J. M.: Meta-analysis of strategies to control nitrate leaching in irrigated agricultural systems and their effects on crop yield, Agriculture, Ecosystems and Environment, 174, 1-10, doi: https://doi.org/10.1016/j.agee.2013.04.018, 2013.

R Development Core Team: R: A language and environment for statistical computing. R Foundation for Statistical Computing, Vienna, Austria, 2016.

Ranaivoson, L., Naudin, K., Ripoche, A., Rabeharisoa, L., and Corbeels, M.: Effectiveness of conservation agriculture in increasing crop productivity in low-input rainfed rice cropping systems

under humid subtropical climate, Field Crops Research, 239, 104-113, doi: https://doi.org/10.1016/j.fcr.2019.05.002, 2019.

Rosegrant, M. W., Koo, J., Cenacchi, N., Ringler, C., Robertson, R. D., Fisher, M., Cox, C. M., Garrett, K., Perez, N. D., and Sabbagh, P.: Food security in a world of natural resource scarcity: The role of agricultural technologies., International Food Policy Research Institute (IFPRI), Washington, D.C., 2014.

Rosenzweig, C., Mbow, C., Barioni, L. G., Benton, T. G., Herrero, M., Krishnapillai, M., Liwenga, E. T., Pradhan, P., Rivera-Ferre, M. G., Sapkota, T., Tubiello, F. N., Xu, Y., Mencos Contreras, E., and Portugal-Pereira, J.: Climate change responses benefit from a global food system approach, Nature Food, 1, 94-97, doi: https://doi.org/10.1038/s43016-020-0031-z, 2020.

SARE: Cover Crop Economics-Opportunities to Improve Your Bottom Line in Row Crops. Agriculture Innovation, Technical Bulletin, Sustainable Agriculture Research and Education, USA, 2019.

Schaphoff, S., Forkel, M., Müller, C., Knauer, J., von Bloh, W., Gerten, D., Jägermeyr, J., Lucht, W., Rammig, A., Thonicke, K., and Waha, K.: LPJmL4 - a dynamic global vegetation model with 685 managed land - Part 2: Model evaluation, Geoscientific Model Development 11, 1377-1403, doi: https://doi.org/10.5194/gmd-11-1377-2018, 2018a. 
https://doi.org/10.5194/bg-2021-215

Preprint. Discussion started: 1 September 2021

(c) Author(s) 2021. CC BY 4.0 License.

Schaphoff, S., von Bloh, W., Rammig, A., Thonicke, K., Biemans, H., Forkel, M., Gerten, D., Heinke, J., Jägermeyr, J., Knauer, J., Langerwisch, F., Lucht, W., Müller, C., Rolinski, S., and Waha, K.: LPJmL4 - a dynamic global vegetation model with managed land - Part 1: Model description,

Geoscientific Model Development 11, 1343-1375, doi: https://doi.org/10.5194/gmd-11-1343-2018, 2018b.

Scopel, E., Triomphe, B., Affholder, F., Da Silva, F. A. M., Corbeels, M., Xavier, J. H. V., Lahmar, R., Recous, S., Bernoux, M., Blanchart, E., de Carvalho Mendes, I., and De Tourdonnet, S.: Conservation agriculture cropping systems in temperate and tropical conditions, performances and impacts. A review, Agronomy for Sustainable Development, 33, 113-130, doi: https://doi.org/10.1007/s13593-012-0106-9, 2013.

Siebert, S., Portmann, F. T., and Döll, P.: Global Patterns of Cropland Use Intensity, Remote Sensing, 2, 1625-1643, doi: 10.3390/rs2071625, 2010.

Smith, P.: Soil carbon sequestration and biochar as negative emission technologies, Global Change Biology, 22, 1315-1324, doi: https://doi.org/10.1111/gcb.13178, 2016.

Sommer, R. and Bossio, D.: Dynamics and climate change mitigation potential of soil organic carbon sequestration, Journal of Environmental Management, 144, 83-87, doi: https://doi.org/10.1016/j.jenvman.2014.05.017, 2014.

Springmann, M., Clark, M., Mason-D’Croz, D., Wiebe, K., Bodirsky, B. L., Lassaletta, L., de Vries, W., Vermeulen, S. J., Herrero, M., Carlson, K. M., Jonell, M., Troell, M., DeClerck, F., Gordon, L. J., Zurayk, R., Scarborough, P., Rayner, M., Loken, B., Fanzo, J., Godfray, H. C. J., Tilman, D., Rockström, J., and Willett, W.: Options for keeping the food system within environmental limits, Nature, 562, 519-525, doi: https://doi.org/10.1038/s41586-018-0594-0, 2018.

Stockmann, U., Adams, M. A., Crawford, J. W., Field, D. J., Henakaarchchi, N., Jenkins, M., Minasny, B., McBratney, A. B., Courcelles, V. d. R. d., Singh, K., Wheeler, I., Abbott, L., Angers, D. A., Baldock, J., Bird, M., Brookes, P. C., Chenu, C., Jastrow, J. D., Lal, R., Lehmann, J., O’Donnell, A. G., Parton, W. J., Whitehead, D., and Zimmermann, M.: The knowns, known unknowns and unknowns of sequestration of soil organic carbon, Agriculture, Ecosystems and Environment, 164, 8099, doi: https://doi.org/10.1016/j.agee.2012.10.001, 2013.

Su, Y., Gabrielle, B., and Makowski, D.: A global dataset for crop production under conventional tillage and no tillage systems, Scientific Data, 8, 33, doi: https:/doi.org/10.1038/s41597-021-00817-x, 2021.

Thapa, R., Mirsky, S. B., and Tully, K. L.: Cover Crops Reduce Nitrate Leaching in Agroecosystems: A Global Meta-Analysis, Journal of Environmental Quality, 47, 1400-1411, doi: https://doi.org/10.2134/jeq2018.03.0107, 2018.

Thierfelder, C., Baudron, F., Setimela, P., Nyagumbo, I., Mupangwa, W., Mhlanga, B., Lee, N., and Gérard, B.: Complementary practices supporting conservation agriculture in southern Africa. A review, Agron. Sustain. Dev., 38, 16, doi: https://doi.org/10.1007/s13593-018-0492-8, 2018. 
https://doi.org/10.5194/bg-2021-215

Preprint. Discussion started: 1 September 2021

(c) Author(s) 2021. CC BY 4.0 License.

Tittonell, P., Scopel, E., Andrieu, N., Posthumus, H., Mapfumo, P., Corbeels, M., van Halsema, G. E.,

Lahmar, R., Lugandu, S., Rakotoarisoa, J., Mtambanengwe, F., Pound, B., Chikowo, R., Naudin, K., Triomphe, B., and Mkomwa, S.: Agroecology-based aggradation-conservation agriculture (ABACO): Targeting innovations to combat soil degradation and food insecurity in semi-arid Africa, Field Crops Research, 132, 168-174, doi: http://dx.doi.org/10.1016/j.fcr.2011.12.011, 2012.

Tonitto, C., David, M. B., and Drinkwater, L.: Replacing Bare Fallows with Cover Crops in FertilizerIntensive Cropping Systems: A Meta-Analysis of Crop Yield and N Dynamics, Agriculture, Ecosystems and Environment, 112, 58-72, doi: https://doi.org/10.1016/j.agee.2005.07.003, 2006.

Valkama, E., Lemola, R., Känkänen, H., and Turtola, E.: Meta-analysis of the effects of undersown catch crops on nitrogen leaching loss and grain yields in the Nordic countries, Agriculture, Ecosystems and Environment, 203, 93-101, doi: https://doi.org/10.1016/j.agee.2015.01.023, 2015.

von Bloh, W., Schaphoff, S., Müller, C., Rolinski, S., Waha, K., and Zaehle, S.: Implementing the nitrogen cycle into the dynamic global vegetation, hydrology, and crop growth model LPJmL (version 5.0), Geoscientific Model Development 11, 2789-2812, doi: https://doi.org/10.5194/gmd-11-27892018, 2018.

Waha, K., Dietrich, J. P., Portmann, F. T., Siebert, S., Thornton, P. K., Bondeau, A., and Herrero, M.: Multiple cropping systems of the world and the potential for increasing cropping intensity, Global Environmental Change, 64, 102131, doi: https://doi.org/10.1016/j.gloenvcha.2020.102131, 2020.

West, T. O., Marland, G., King, A. W., Post, W. M., Jain, A. K., and Andrasko, K.: Carbon Management Response Curves: Estimates of Temporal Soil Carbon Dynamics, Environmental Management, 33, 507-518, doi: 10.1007/s00267-003-9108-3, 2004.

West, T. O. and Six, J.: Considering the influence of sequestration duration and carbon saturation on estimates of soil carbon capacity, Climatic Change, 80, 25-41, doi: https://doi.org/10.1007/s10584006-9173-8, 2007.

Wittwer, R. A., Dorn, B., Jossi, W., and van der Heijden, M. G. A.: Cover crops support ecological intensification of arable cropping systems, Scientific Reports, 7, 41911, doi: https://doi.org/10.1038/srep41911, 2017.

Zhu, B., Yi, L., Guo, L., Chen, G., Hu, Y., Tang, H., Xiao, C., Xiao, X., Yang, G., N. Acharya, S., and Zeng, Z.: Performance of two winter cover crops and their impacts on soil properties and two subsequent rice crops in Dongting Lake Plain, Hunan, China, Soil Tillage Res., 124, 95-101, doi: https://doi.org/10.1016/j.still.2012.05.007, 2012.

Zomer, R. J., Bossio, D. A., Sommer, R., and Verchot, L. V.: Global Sequestration Potential of Increased Organic Carbon in Cropland Soils, Scientific Reports, 7, 15554, doi: https://doi.org/10.1038/s41598-017-15794-8, 2017. 